\title{
$\alpha$-Glucosidases of Candida tropicalis var. japonica
}

\author{
by Teruo SAWAI*
}

沢井輝男：Candida tropicalis var. japonica の $\alpha$-グルコシダーゼ

\section{Received November 11, 1955}

Candida tropicalis var. japonica is a strain of the wild yeast, which was isolated in 1942 by Hoshino from a soil wet with sulfite waste liquor. At that time Yamaguchi (1) named this yeast Mycotorula japonica var. $K$. $H$., but recently Kobayashi (2) proposed to rename it as mentioned according to Lodder and Kreger-Van Rij's new nomenclature of the yeast (3). As this yeast possesses strong ability to utilize xylose, several studies have so far been made with regard to the yeast manufacture using sulfite waste liquor $(4,5,6)$. As to the enzyme of this yeast a study of amylase was made by Yamaguchi (7), that of xylokinase by Sawai (8), and with another strain of $C$. tropicalis that of trehalase by Lukes and Phaff (9). The present author attempted to investigate other carbohydrases of this yeast. This paper deals with the descriptions about the kinds and some properties of $\alpha$-glucosidases which act upon four substrates: sucrose, maltose, methyl- $\alpha$-glucoside and trehalose.

\section{Methods}

The yeast was grown in a semisynthetic medium. Basal medium contained per liter (distilled water + tap water, $9: 1) 6$ gr. of $\left(\mathrm{NH}_{4}\right)_{2} \mathrm{SO}_{4}, 2$ gr. of $\mathrm{KH}_{2} \mathrm{PO}_{4}, 0.9$ gr. of $\mathrm{MgSO}_{4} \cdot 7 \mathrm{H}_{2} \mathrm{O}, 0.3 \mathrm{gr}$. of $\mathrm{CaCl}_{2} \cdot 2 \mathrm{H}_{2} \mathrm{O}$ and $30 \mathrm{ml}$. of yeast extract. $100 \mathrm{ml}$. or 160 $\mathrm{ml}$. of this solution were given to $500 \mathrm{ml}$. flasks, sterilized, and added with carbon source (sucrose, methyl- $\alpha$-glucoside, dextrin, starch, mannose or mannitol) in the form of aqueous solution which had been separately sterilized so as to make 4 to 7 per cent in the final medium. The flasks, after inoculation with the yeast which had been precultured in the same medium containing glucose, were shaken for two days in an incubator at $30^{\circ}$. The cells were harvested by centrifugation and washed twice with distilled water.

Three different sorts of enzyme preparation were used for the experiments, which were prepared as follows. (a) The washed cells were treated with chilled acetone and dried in vacuo over $\mathrm{P}_{2} \mathrm{O}_{5}$. The dried cells thus obtained were suspended in distilled water - unless otherwise stated, $0.30 \mathrm{gr}$. in $60 \mathrm{ml}$. water - and kept overnight in a refrigerator. This was designated as "dry cell suspension". As

\footnotetext{
* Biological Institute, Aichi Gakugei University, Nagoya, Japan 愛知学芸大学生物学教空
} 
preliminary experiments showed that the activity of each $\alpha$-glucosidase of this yeast varied remarkably depending on the carbon source of the culture media, various samples of the dry cell suspensions which had been obtained with different carbon sources were used. (b) The washed cell paste was mixed about 5 per cent its weight of toluene and 0.3 to 0.5 per cent of $\left(\mathrm{NH}_{4}\right)_{2} \mathrm{HPO}_{4}$, autolyzed overnight at $25^{\circ}$ or $30^{\circ}$, and after dilution with distilled water, kept overnight in a refrigerator. The autolyzate was centrifuged and the supernatant liquid, having been cleared by filtration, was dialyzed overnight in a cellophane bag against diluted buffer of $\mathrm{pH}$ 4.0 or 6.6 in the cold. This was designated as "autolyzate". (c) The autolyzate was treated with alumina gel $\mathrm{B}$ at $\mathrm{pH} 5.5$ to 5.8 and the enzyme was eluted with 1 per cent solution of $\left(\mathrm{NH}_{4}\right)_{2} \mathrm{HPO}_{4}$. This eluate designated as “B-eluate". For $\mathrm{pH}$ adjustment of these enzyme solutions $0.5 \mathrm{~N} \mathrm{NH}_{4} \mathrm{OH}$ or acetic acid was used. All these enzyme preparations contained no fermentation system for glucose.

Methyl- $\alpha$-glucoside was synthesized in our laboratory. Methyl- $\beta$ - $h$-fructoside was prepared with the aid of the transfructosidase activity of yeast invertase (10). Other substrates - sucrose, maltose, raffinose and trehalose - were the commercial products of the reagent grade.

The reaction mixture consisted of $1 \mathrm{ml}$. of substrate solution (final concentration, $0.02 \mathrm{M}), 1 \mathrm{ml}$. of $\mathrm{HCl}$-citrate or phosphate-citrate buffer solution and $2 \mathrm{ml}$. of enzyme solution. The reaction vessels were incubated at $30^{\circ}$ with occasional shaking. After suitable lapse of time the enzyme action was stopped by the addition of $4 \mathrm{ml}$. or $12 \mathrm{ml}$. of 2 per cent sodium carbonate solution and the increase in the reducing power was determined by the Somogyi's improved method (11). The percentage of the hydrolysis was obtained from the graphs constructed beforehand with each sugar. The enzyme activity was expressed in terms of the velocity constant $(k)$ of the first order reaction, calculated with minutes as the time unit.

\section{Results}

(1) Neutral $\alpha$-glucosidase group. The dry cell suspension obtained from the cultures grown with sucrose as carbon source hydrolyzed sucrose, maltose and methyl$\alpha$-glucoside with the optimum pH of 6.1 to 6.6 (Fig. 1). This figure shows that below $\mathrm{pH} 4.0$ this dry cell suspension acted upon none of these substrates. The enzymes containd in this suspension were found to be relatively labile, their activity being nearly lost by keeping the suspension overnight at $\mathrm{pH} 4.0$ and at $30^{\circ}$. For the purpose of determining whether or not the enzyme which hydrolyzed sucrose optimally at $\mathrm{pH} 6.6$ was $\beta$-h-fructosidase, the behavior of this enzyme toward raffinose and methyl- $\beta-\mathrm{h}$-fructoside together with :sucrose was examined using a B-eluate of high activity obtained by alumina gel adsorption. The results are represented in Fig. 2, which shows that raffinose and $\beta$-h-fructoside remained quite unaffected even after sucrose was completely cleaved, Hence it appears likely that the enzyme hydrolyzing sucrose of this yeast may not be a $\beta$-h-fructosidase but an 


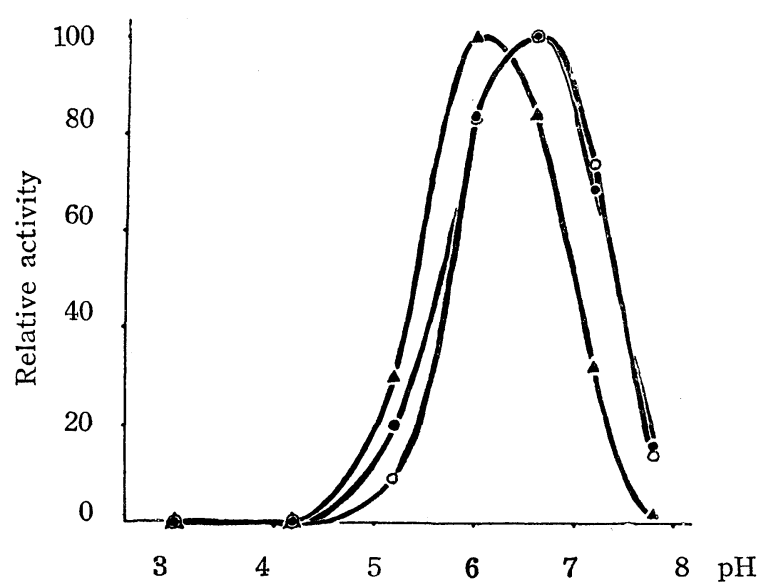

Fig. 1. Activity-pH-curves of the dry cell suspension obtained from the cells grown in a sucrose medium for the hydrolysis of sucrose $(O)$, maltose (2) and methyl- $\alpha$-glucoside ( $\boldsymbol{A}$ ). Period of incubation: $180 \mathrm{~min}$.

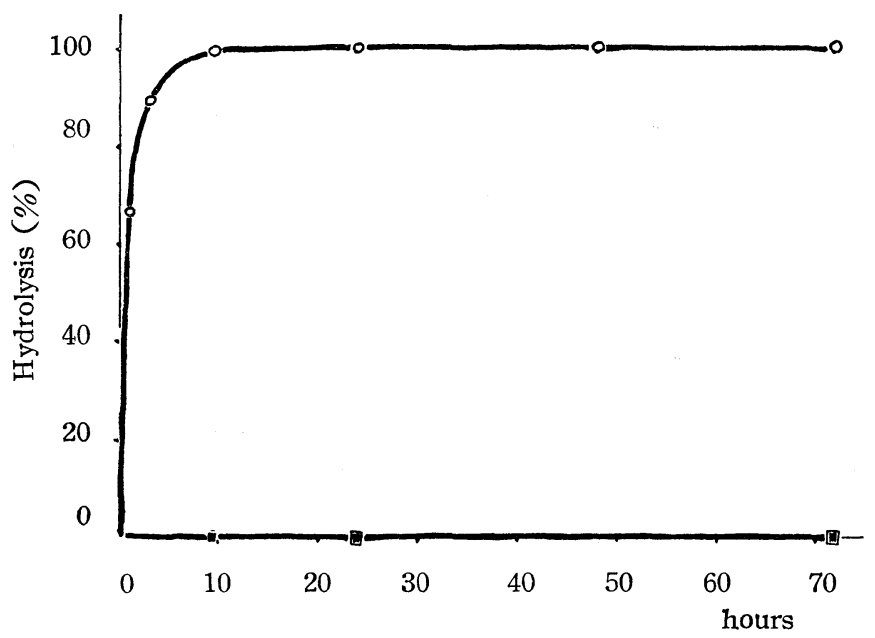

Fig. 2. Time-course of the hydrolysis of sucrose $(O)$, raffinose $(\square)$ and methyl- $\beta$-h-fructoside $(\square)$ at $\mathrm{pH} 6.5$ by the B-eluate obtained from the cells grown in a sucrose medium.

$\alpha$-glucosidase.

In order to make clear whether one and the same enzyme is responsible for the hydrolysis of sucrose, maltose and methyl- $\alpha$-glucoside or several specific enzymes are concerned, activity ratios toward these substrates were examined using a dry cell suspension and two kinds of autolyzates. The results are summarized in Table 1 , which shows that the ratios of activity toward three substrates fluctuate quite irregularly. This fact might suggest that at least three kinds of the $\alpha$-glucosidases would be involved in the hydrolysis of these substrates, but it is obscure whether or not each enzyme is responsible respectively for the hydrolysis of a single substrate. Accordingly they were referred to collectively as neutral $\alpha$-glucosidase group. 
Table 1. Activity of the neutral $\alpha$-glucosidase group for the hydrolysis of sucrose, maltose and methyl- $\alpha$-glucoside. As enzyme a dry cell suspension and two autolyzates were used which were obtained from the cells grown in a sucrose medium. The autolyzates were fractionated or partially inactivated as indicated. Reaction was carried out at $\mathrm{pH} 6.6$ with sucrose and maltose and at $\mathrm{pH} 6.1$ with methyl$\alpha$-gludoside.

\begin{tabular}{|c|c|c|c|c|c|c|c|c|}
\hline \multirow{2}{*}{$\begin{array}{l}\dot{0} \\
\dot{z} \\
\dot{x} \\
\text { 至 }\end{array}$} & \multirow{2}{*}{$\begin{array}{l}\text { Enzyme } \\
\text { preparaticn }\end{array}$} & & \multicolumn{3}{|c|}{$\begin{array}{c}\text { Velocity constant, } \\
10^{4} \cdot k\end{array}$} & \multicolumn{3}{|c|}{ Activity ratio $*$} \\
\hline & & & Sucrose & Maltose & Me- $\alpha$-gl. & Sucrose & Maltose & $\mathrm{Me}-\alpha-\mathrm{gl}$ \\
\hline 1 & Dry cell suspension & 180 & 2.41 & 1.52 & 2.04 & 100 & 63 & 85 \\
\hline \multirow{3}{*}{2} & $\begin{array}{l}\text { Autolyzate untreated } \\
\text { (control) }\end{array}$ & 120 & 20.34 & 10.03 & 11.89 & 100 & 49 & 58 \\
\hline & $\begin{array}{l}\text { Autolyzate acidified } \\
\text { to } \mathrm{pH} 4.0 \text { and warmed } \\
\text { at } 30^{\circ} \text { for } 40 \mathrm{~min} \text {. }\end{array}$ & 210 & 6.68 & 4.88 & 0.50 & 100 & 73 & 7 \\
\hline & $\begin{array}{l}\text { Aqueous solution of } \\
\text { the precipitate ob- } \\
\text { tained by acetone } \\
\text { treatment } * *\end{array}$ & 210 & 8.28 & 5.35 & 0.63 & 100 & 65 & 8 \\
\hline \multirow{3}{*}{3} & $\begin{array}{l}\text { Autolyzate untreated } \\
\text { (control) }\end{array}$ & 1080 & 3.49 & 3.99 & 0.59 & 100 & 114 & 14 \\
\hline & $\begin{array}{l}\text { Autolyzate heated at } \\
50^{\circ} \text { for } 7 \text { min. }\end{array}$ & 1080 & 0.58 & 2.32 & 0.23 & 100 & 400 & 40 \\
\hline & $\begin{array}{l}\text { Aqueous solution of } \\
\text { the precipitate ob- } \\
\text { tained by tannin } \\
\text { treatment }\end{array}$ & 1080 & 0.65 & 0.58 & 0.20 & 100 & 89 & 31 \\
\hline
\end{tabular}

* Activity for sucrose was taken as 100 .

** Acetone treatment required 3.5 hours at room temperature.

(2) Acid $\alpha$-glucosidase. With any other carbon source than sucrose such as methyl- $\alpha$-glucoside, maltose, dextrin, starch or mannitol, this Candida yeast produced in addition to the neutral $\alpha$-glucosidase group other enzymes which hydrolyzed maltose and methyl- $\alpha$-glucoside optimally in more acid range. Fig. 3 shows the activity-pH-curves of the autolyzate obtained from the cultures in a dextrin medium for the hydrolysis of maltose and methyl- $\alpha$-glucoside. The neutral $\alpha$-glucosidases in the autolyzate had been destroyed by keeping it overnight at $\mathrm{pH} 4.0$ and at $30^{\circ}$. It can be seen in Fig. 3 that for both substrates the optimum pH lies at about 4. 0 , where the neutral $\alpha$-glucosidases are inactive. These enzymes were found to be stable enough to retain their entire activity even if the cell suspension was kept overnight at $\mathrm{pH} 3.5$ and at $30^{\circ}$ in contrast with the neutral $\alpha$-glucosidase group, the activity of which was lost under these conditions (Table 2). The activity of 


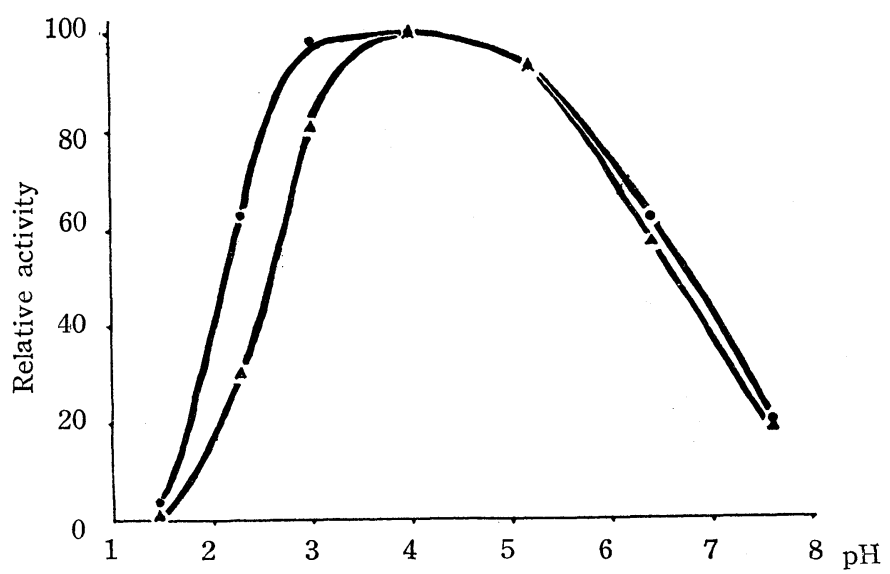

Fig. 3. Activity-pH-curves of the autolyzate obtained from the cells grown in a dextrin medium for the hydrolysis of maltose (e) and methyl$\alpha$-glucoside ( $\boldsymbol{\Delta}$ ). The autolyzate was freed from neutral $\alpha$-glucosidases. Period of incubation: $180 \mathrm{~min}$. with maltose and $1200 \mathrm{~min}$. with methyl- $\alpha$-glucoside.

Table 2. Stability in the acid medium of the $\alpha$-glucosidase activity of the dry cell suspension obtaind from the cells grown in a dextrin medium. The activity for maltose and methyl- $\alpha$-glucoside was measured at $\mathrm{pH}$ 4.0. Period of incubation: $240 \mathrm{~min}$. with maltose and $1410 \mathrm{~min}$. with methyl- $\alpha$-glucoside.

\begin{tabular}{|c|c|c|c|c|}
\hline \multirow[b]{2}{*}{ Dry cell suspension } & \multicolumn{2}{|c|}{$\begin{array}{c}\text { Velocity constant, } \\
10^{4 \cdot k}\end{array}$} & \multicolumn{2}{|c|}{ Relative activity * } \\
\hline & Maltose & $\mathrm{Me}-\alpha-\mathrm{gl}$ & Maltose & $\mathrm{Me}-\alpha-g l$ \\
\hline Control & 3.16 & 0.14 & 100 & 100 \\
\hline $\begin{array}{l}\text { Kept overnight at } \\
\text { pH } 3.5 \text { and at } 30^{\circ}\end{array}$ & 3.31 & 0.15 & 104.7 & 107.1 \\
\hline
\end{tabular}

* Activity of the control suspension was taken as 100 .

these acid active enzymes toward sucrose was tested at $\mathrm{pH} 4.0$ using an autolyzate of relatively high activity which was obtained from the cultures with dextrin. As illustrated in Fig. 4, however, sucrose was not attacked even after the ihcubation of 40 hours when maltose was almost completely hydrolyzed. These observations indicate that this Candia yeast does not produce such invertase as is contained in Saccharomyces yeast.

In order to make clear whether or not maltose and methyl- $\alpha$-glucoside were hydrolyzed by the one and the same acid active enzyme the ratios of activity toward these two substrates were examined using three kinds of dry cell suspensions and one of the autolyzate. The results are summarized in Table 3 , which shows that the activity ratios are almost constant among these enzyme preparations though the specific activity toward each substrate varied more or less considerably with 


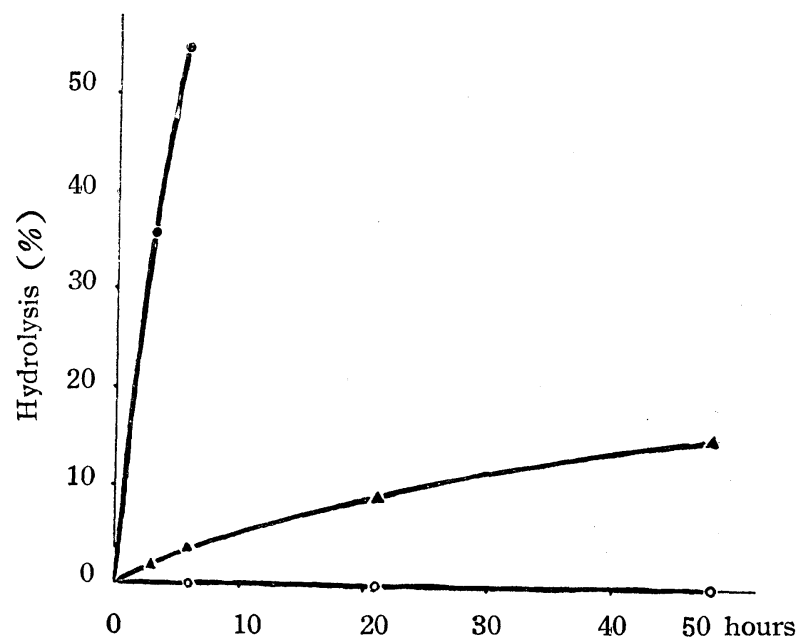

Fig. 4 Time-course of the hydrolysis of maltose $(\bullet)$, sucrose $(\bigcirc)$ and methyl- $\alpha$-glucoside $(\boldsymbol{\Lambda})$ at $\mathrm{pH} 4.0$ by the autolyzate obtained from the cells grown in a dextrin medium.

different enzyme preparations. Hence it appears likely that maltose and methyl$\alpha$-glucoside would be hydrolyzed by a single enzyme. This enzyme was thus named as acid $\alpha$-glucosidase.

Table 3. Activity of three different dry cell suspensions and of an autolyzate for the hydrolysis of maltose and methyl- $\alpha$-glucoside at $\mathrm{pH} 4.0$. The autolyzate was treated in two ways.

\begin{tabular}{|c|c|c|c|c|c|c|c|c|}
\hline \multirow{3}{*}{$\begin{array}{l}\text { C-source } \\
\text { used for } \\
\text { culture } \\
\text { Dextrin }\end{array}$} & \multirow{2}{*}{\multicolumn{2}{|c|}{$\begin{array}{l}\text { Enzyme } \\
\text { preparation }\end{array}$}} & \multicolumn{2}{|c|}{$\begin{array}{l}\text { Reaction } \\
\text { period, } \\
\text { min. }\end{array}$} & \multicolumn{2}{|c|}{$\begin{array}{l}\text { Velocity } \\
\text { constant, } \\
10^{4} \cdot k^{*}\end{array}$} & \multicolumn{2}{|c|}{$\begin{array}{l}\text { Activity } \\
\text { ratio ** }\end{array}$} \\
\hline & & & \multirow{2}{*}{$\frac{\text { Maltose }}{480}$} & \multirow{2}{*}{$\frac{\mid \text { Me- } \alpha \text {-gl }}{1740}$} & \multirow{2}{*}{$\frac{\text { Maltose }}{17.72}$} & \multirow{2}{*}{$\frac{M e-\alpha-g l}{0.68}$} & \multirow{2}{*}{$\frac{\text { Maltose }}{100}$} & \multirow{2}{*}{$\frac{\text { Me- } \alpha-g l}{3.4}$} \\
\hline & Dry cell suspension & 0.5 & & & & & & \\
\hline $\mathrm{Me}-\alpha-\mathrm{gl}$ & Dry cell suspension & 0.83 & 480 & 1740 & 6.85 & 0.27 & 100 & 4.0 \\
\hline \multirow[t]{2}{*}{ Mannose } & Dry cell suspension & 5.5 & 480 & 1740 & 1.14 & 0.045 & 100 & 3.9 \\
\hline & \multicolumn{2}{|c|}{ Autolyzate untreated (control) } & 180 & 1740 & 7.17 & 0.27 & 100 & 3.7 \\
\hline \multirow[t]{2}{*}{ Dextrin } & \multicolumn{2}{|c|}{ Autolyzate heated at $45^{\circ}$ for 1 hour } & 180 & 1170 & 6.50 & 0.25 & 100 & 3.8 \\
\hline & \multicolumn{2}{|c|}{ Autolyzate heated at $60^{\circ}$ for 1 hour } & 180 & 1170 & 3.19 & 0.14 & 100 & 4.4 \\
\hline
\end{tabular}

* In the case of the dry cell suspensions the velocity constant was divided by mgr. of dry cells per ml. of digest.

** Activity for maltose was taken as 100 .

(3) Trehalase. The dry cell suspension of this Candida yeast grown in a mannitol medium contained a trehalase which hydrolyzed trehalose optimally at $\mathrm{pH}$ 5.2 (Fig 5). The trehalase was contained in varying amounts in the cells grown with various other carbon sources. In order to see whether this trehalase was identical either with the acid $\alpha$-glucosidase or with any one of the neutral $\alpha$-glucosidase group, activity ratios of all these enzyme preparations and the trehalase 
toward four substrates (sucrose, maltose, methyl- $\alpha$-glucoside and trehalose) were determined using three sorts of dry cell suspensions. Table 4 summarizes the results. Since, in the case of two dry cell suspensions which were obtained from the cells grown in the sucrose medium and in the mannitol medium respectively, the activity ratios toward trehalose and each of three substrates of the neutral $\alpha$-glucosidase group varied remarkably, it may be sure that the trehalase differs from any one

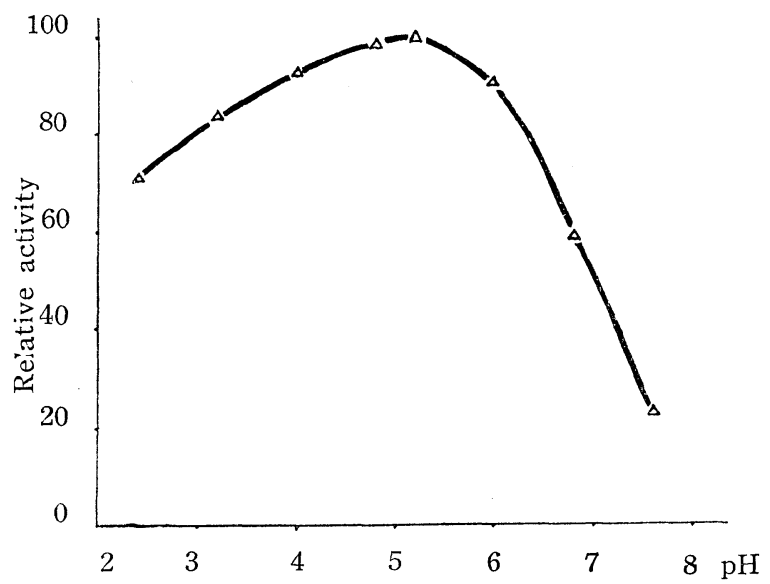

Fig. 5 Activity-pH-curves of the dry cell suspension obtained from the cells grown in a mannitol medium for the hydrolysis of trehalose. Period of incubation: $150 \mathrm{~min}$.

of the neutral $\alpha$-glucosidases. Similarly, the trehalase appears to be distinct from the acid $\alpha$-glucosidase, because there is no parallelism in the activities for trehalose and

Table 4. Activity of the neutral $\alpha$-glucosidase group, the acid $\alpha$-glucosidase and the trehalase contained in the three different sorts of dry cell suspensions.

\begin{tabular}{|c|c|c|c|c|c|c|c|c|c|c|c|}
\hline \multirow[t]{2}{*}{ Enzyme } & \multirow{2}{*}{$\begin{array}{l}\text { Sub- } \\
\text { strate }\end{array}$} & \multirow{2}{*}{ 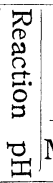 } & \multicolumn{3}{|c|}{$\begin{array}{l}\text { Reaction period } \\
\text { min. }\end{array}$} & \multicolumn{3}{|c|}{$\begin{array}{l}\text { Velocity constant, } \\
10^{4 . k}\end{array}$} & \multicolumn{3}{|c|}{ Activity ratio * } \\
\hline & & & Mannitol & Sucrose & Dextrin' & Mannitol & Sucrose & Dextrin & Mannitol & Sucrose & Dextrin \\
\hline \multirow{3}{*}{$\begin{array}{l}\text { Neutal } \\
\alpha \text {-gluco- } \\
\text { sidase } \\
\text { group }\end{array}$} & Sucrose & 6.6 & 1320 & 150 & & 0.42 & 4.92 & & 4 & 863 & \\
\hline & Maltose & 6.6 & 1320 & 150 & & 0.89 & 3.08 & & 8 & 540 & \\
\hline & Me-x-gl & 6.1 & 1320 & 150 & & 0.07 & 1.61 & & 0.7 & 282 & \\
\hline $\begin{array}{l}\text { Tre- } \\
\text { halase }\end{array}$ & $\begin{array}{l}\text { Treha- } \\
\text { lose }\end{array}$ & 5.2 & 150 & 1320 & 150 & 10.49 & 0.57 & 12.30 & 100 & 100 & 100 \\
\hline $\begin{array}{l}\text { Acid } \\
\alpha \text {-gluco- } \\
\text { sidase }\end{array}$ & Maltose & 4.0 & 1320 & & 150 & 1.51 & & 22.50 & 14 & & 183 \\
\hline
\end{tabular}

* Activity for trehalose was taken as 100 . 
maltose in the two dry cell suspensions which were obtained from mannitol culture and dextrin culture respectively. Therefore it seems probable that the trehalase of this Candida yeast is a specific enzyme that hydrolyzes trehalose alone.

\section{Discussion}

Candida tropicalis var. japonica produces two sorts of maltose hydrolyzing enzymes, the one with the optimum $\mathrm{pH}$ at about 4.0 and the other with that at 6.6. The latter enzyme seems to be, for its lability in the acid medium and its optimum $\mathrm{pH}$ value (Fig. 1). the same as or analogous to the enzyme which has heretofore been known as yeast maltase $(12,13)$. Willstätter et al. (12) reported long ago that the yeast maltase could hydrolyse methyl- $\alpha$-glucoside too. Weidenhagen (14), who discovered that this enzyme could further hydrolyze sucrose, designated it as $\alpha-$ glucosidase and considered that the $\alpha$-glucosidase hydrolyzes generally varicus holosides and heterosides with $\alpha$-glucosidic linkage. In this Candida yeast, however, the author postulated that the enzymes which hydrolyzed maltose, sucrose and methyl- $\alpha-$ glucoside optimally at $\mathrm{pH} 6.1$ to 6.6 consisted of at least three distnct enzyme because the activity ratios of the enzyme preparation toward these three substrates fluctuated quite irregularly upon various treatments. In $1940 \mathrm{Miwa}$ and Toishi (15) observed that the ratio of the activity of yeast $\alpha$-glucosidase toward maltose and methyl- $\alpha$-glucoside fluctuated more or less significantly upon fractionation of the enzyme preparation and suggested that maltase and methyl- $\alpha$-glucosidase of brewer's yeast might be separate enzymes. Recently Lindegren and his associates $(16,17)$ reported that they could obtain from haploid Saccharomyces strains maltase, sucrase and methyl- $\alpha$-glucosidase each of which acted specifically upon a corresponding single substrate. In view of these findings it may be possible to infer that in our neutral $\alpha$-glucosidase group of this Candida yeast as least three distinct enzymes may be involved, each acting exclusively upon sucrose, maltose and methyl- $\alpha$ glucoside respectively.

On the contrary, the acid $\alpha$-glucosidase may be regarded as an enzyme which hydrolyzed both maltose and methyl- $\alpha$-glucoside, since the ratios of activity toward these substrates remained nearly constant in different enzyme preparations, as shown in Table 3. However, this $\alpha$-glucosidase did not act upon sucrose, a fact which is at variance with the Weidenhagen's theory. In this respect it resembles rather the maltases found in Schizosaccharomyces octosporus (18) or Escherichia coli (19, 20). While Hofmann could not obtain a decisive evidence for the identity of maltase and methyl- $\alpha$-glucosidase of the Schizosaccharomyces yeast (18), it appears of interest that the average activity ratio of the Candida acid $\alpha$-glucosidase for the hydrolysis of maltose and methyl- $\alpha$-glucoside, $100: 3.9$, is close to that of the Schizosaccharomyces yeast, $100: 2.8$, when calculated from the Hofmann's data.

Based on the observations that the ratio of activity toward maltose and trehalose differs between the enzyme preparation of baker's yeast and that of brewer's yeast 
and that the stability of each enzyme preparation differs in respect of two substrates, Myrbäck and Örtenfeld (21) considered that maltase and trehalase were different enzymes. In the present work more reliable data were obtained for proving the non-identity of the trehalase with the acid $\alpha$-glucosidase and also with each of the neutral $\alpha$-glucosidase group of a Candida yeast strain (Table 4 ). It is worthy to note that the optimum $\mathrm{pH}$ of this Candida trehalase, namely about 5.2, was the same as well as that of the trehalase found by Lukes and Phaff (9) in the cells of another strain of Candida tropicalis while it differs from that of the trehalase of the brewer's yeast which lies at about 7.2 (21).

The experimental data obtained in the present work are strongly suggestive of the absence of $\beta$-h-fructosidase in the cells of Candida tropicalis var. japonica (Fig. 2 and 4 ). In this respect the constitution of the carbohydrase system of this Candida yeast seems of particular interest.

\section{Summary}

Candida tropicalis var. japonica was proved to produce following three sorts of $\alpha$-glucosidases.

(1) Neutral $\alpha$-glucosidase group. The enzyme included in this group hydrolyzed sucrose, maltose and methyl- $\alpha$-glucoside optimally at $\mathrm{pH} 6.1$ to 6.6 , but not below $\mathrm{pH}$ 4.0. In this group at least three different enzymes seem to de involved, but the separation of the enzymes was not successful.

(2) Acid $\alpha$-glucosidase. This enzyme hydrolyzed both maltose and methyl$\alpha$-glucoside optimally at about $\mathrm{pH} 4.0$, but not sucrose at all. The activity ratio of this enzyme toward these two substrates was about $100: 3.9$.

(3) Trehalase. This enzyme hydrolyzed trehalose alone optimally at pH 5.2 and was proved to differ from any other $\alpha$-glucosidases mentioned above. $\beta-\mathrm{h}-$ Fructosidase appeared to be absent in this yeast strain.

The author wishes to express his hearty thanks to Prof. T. Miwa for his instruction and encouragement and also for reading the manuscript before publication. Thanks are also tendered to Prof. K. Nisizawa for his helpful advice. The yeast strain used in this work was beforehand further purified from the stock culture maintained in the author's laboratory by courtesy of Prof. T. Kobayashi, to whom the author is indebted to acknowledge.

\section{Bibliography}

1. Yamaguchi, K., J. Agr. Chem. Soc. Japan 19: 800 (1945). 2. Kobayashi, T., Report of the Wood Saccharification Discussion Committee 2: 35 (1953). 3. Lodder, J. \& Kreger-Van Rij, N. J. W., The Yeasts (1952). 4. Kihara, H., Sato, T. \& Yamaguchi, T., J. Agr. Chem. Soc Japan 22: 45 (1948). 5. Yamada, K., Ito, T., Koyama, A. \& Handa, Y., ibid. 25: 173 (1951). 6. Miwa, M., J. Ferment. Technol. 30 Suppl.: 297 (1952). 7. Yamaguchi, K., J. Agr. Chem. Soc. Japan 28 : 415 (1954). 8. Sawai. T., Bull Aichi Gakugei Univ. 2: 56 (1953). 9. Lukes, T. M. \& Phaff, H. J., Antonie van Leeuwenhoek. J. Microbiol. Serol. 18 : 323 (1952). 10. Miwa, T., Symp. Enzymol. Chem. 8: 57 (1953). 11. Somogyi, M., J. Biol. Chem. $195: 19$ (1952). 12. Willstätter, R., Kuhn R. \& Sobotka, H., Z. physiol. Chem. 129: 33 (1923). 13. Jsaiev, V. J., J. Inst. Brew. 32: 552 (1926). 14. Weidenhagen, R.. Ergebn. Enzymf. 1: 168 (1932). 15. Miwa, T. \& Toishi. A., Bull. Japan. Chem. Soc. 61: 35 (1940). 16. Lindegren, C. C. \& Lindegren, G., Proc. Nat. Acad. Sci. U. S. A. 35 : 23 (1949). 17. Hestrin, S. \& Lindegren, G., Nature 165: 158 (1950). 18. Hofmann, E., Biochem. Z. 272 : 417 (1834). 19. Karström, H., ibid. 231: 399 (1931). 20. Hotchikis, M., J. Bact. 29: 391 (1935). 21. Myrbäck, K. \& Örtenfeld, B., Biochem. Z. 291 : 61 (1937). 